\title{
Risk Factor Assessment of Coal Mine Drainage Water on Surrounding Agricultural Soil: A Case Study at Barapukuria in Bangladesh
}

\author{
Sharmin Sultana, Pradip Kumar Biswas*, Aminur Rahman, Shanjida Sultana, \\ Mohammad Nazim Zaman \\ Institute of Mining, Mineralogy and Metallurgy, Bangladesh Council of Scientific and Industrial Research, \\ Khonjonpur, Joypurhat, Bangladesh \\ Email: pradip_immm@yahoo.com
}

Received 9 November 2015; accepted 30 January 2016; published 4 February 2016

Copyright (C) 2016 by authors and Scientific Research Publishing Inc.

This work is licensed under the Creative Commons Attribution International License (CC BY). http://creativecommons.org/licenses/by/4.0/

(c) ()

\section{Abstract}

This study is performed to know the contamination level of heavy metals on the surrounding agricultural soils at the site of Barapukuria Coal Mine Company Limited (BCMCL). Total concentrations of eight heavy metals ( $\mathrm{Cu}, \mathrm{As}, \mathrm{Cd}, \mathrm{Zn}, \mathrm{Pb}, \mathrm{Cr}$, $\mathrm{Ni}$ and $\mathrm{Mn}$ ) were measured in that soil. To calculate the contamination level, the enrichment factor $(E F)$, geoaccumulation index $\left(I_{\text {geo }}\right)$ and Hakanson potential ecological risk index were done. $I_{g e o}$ values indicated that the study areas at all stations were suffering from moderate contamination with As. The results of enrichment factor revealed that soils in all stations were in extremely high enrichment condition by As metal. Under Hakanson potential ecological risk index, the contamination coefficient $\left(C_{f}^{i}\right)$ and potential ecological risk index $\left(E_{r}^{i}\right)$ were calculated. The degree of contamination at BCMCL area reflects moderate contamination. By considering the ecological risk index of a particular heavy metal, the order is as follows: $\mathrm{Cd}>\mathrm{As}>\mathrm{Cu}>\mathrm{Pb}>\mathrm{Ni}>\mathrm{Cr}>\mathrm{Zn}$ and $\mathrm{Cd}$ has the highest risk index and poses the greatest damage to the BCMCL area's soil. $E F, I_{g e o}$ values and potential ecological risk index indicate that there is considerable As and Cd pollution, mainly caused by coal mine drainage water.

\section{Keywords}

Barapukuria Coal Mine, Heavy Metal, Contamination Coefficient, Enrichment Factor, Geoaccumulation Index, Potential Ecological Risk Index

\footnotetext{
"Corresponding author.
}

How to cite this paper: Sultana, S., Biswas, P.K., Rahman, A., Sultana, S. and Zaman, M.N. (2016) Risk Factor Assessment of Coal Mine Drainage Water on Surrounding Agricultural Soil: A Case Study at Barapukuria in Bangladesh. Journal of Geoscience and Environment Protection, 4, 7-17. http://dx.doi.org/10.4236/gep.2016.42002 


\section{Introduction}

Barapukuria coal mine is the first developed coal mine in Bangladesh. Here underground mine water discharged through the drainage system and is usually used for irrigational purpose in the adjoining area. Pollution of water bodies and soil with mine drainage is a major environmental concern worldwide. As coal mine discharge is frequently acidic and contains high concentrations of metals and metalloids, it can create problems of groundwater, surface water and topsoil in the surrounding area of the mine. The low $\mathrm{pH}$ water dissolves and mobilizes metals from coal and residue deposits [1], thereby adversely impacting on aquatic life and the surrounding vegetation [2]. Barapukuria coal mine has the potential of polluting groundwater, surface water and soil quality in the surrounding area of mine site with mine discharge water. Little concentration of heavy metal can create harm and long-term effect on the soil and so on to the plant. Varying levels of heavy metals tend to accumulate in coal mining areas. In addition to damage structure, function and quality of soils, this heavy metal contamination directly affects human health and development. The soil heavy metals in the environment are relatively stable and difficult to remove through natural processes [3].

The present study is carried out to explore the degree \& spatial distribution of metal contamination in agricultural soils in the vicinity of Barapukuria coal mine in northern part of Bangladesh. To measure the contamination level of heavy metals, enrichment factor and geoaccumulation index were used. Hakanson potential ecological risk index was done to assess the risk factor of heavy metals.

\section{Materials and Methods}

\subsection{Study Region}

The Barapukuria Coal Mine Company Limited (BCMCL) is located near Barapukuria village of Hamidpur union council under Parbatipur thana, Dinajpur district. The study area and its adjoining area is situated at the northern part of Bangladesh and the area lies between latitudes $25^{\circ} 31^{\prime} \mathrm{N}$ to $25^{\circ} 35^{\prime} \mathrm{N}$ and longitude $88^{\circ} 57^{\prime} \mathrm{E}$ to $88^{\circ} 59^{\prime} \mathrm{E}$ (shown in Figure 1) included in the survey of Bangladesh topographic sheet No. 78 c/14.

\subsection{Soil Sample Collection and Processing}

A total of nine topsoil ( 0 - $30 \mathrm{~cm}$ depth) samples were collected from the discharge canal at definite linear distance of about $200 \mathrm{~m}$ during the time of July, 2012. We have taken soil samples from nine different stations. Samples were collected by using a hand auger (a stainless steel screw) and a spade. Samples were taken in a clean polyethylene bags to avoid contaminations. Samples were well labeled with sample ID i.e., St-1 to St-9. Wet samples were air dried before placing in the plastic bags. Soil samples were analyzed in the laboratories of Institute of Mining, Mineralogy and Metallurgy (IMMM), Bangladesh Council of Scientific and Industrial Research (BCSIR), Joypurhat.

\subsection{Analysis and Determination of Heavy Metals}

The selected sediment samples were crushed for 20 min in a planetary ball mill (PM-200, Restsch, Germany) to make powder. The powder samples were then pulverized in a pulverizer machine. The finely ground powder $(<75 \mathrm{um})$ was then put in a porcelain crucible and dried at $100^{\circ} \mathrm{C}$ in an oven overnight to remove moisture. The dried powder samples were mixed with binder (stearic acid: sample at a ratio of 1:10) and pulverized for two minutes. The resulting mixture was spooned into an aluminum cap (30 mm). The cap was sandwiched between two tungsten carbide pellets using a manual hydraulic press with 10 tons/sq. in. for 2 min and finally pressure was released slowly. The pellet was then ready for X-Ray analysis. The elements were determined by X-ray fluoresecence (XRF) in the Institute of Mining, Mineralogy and Metallurgy, BCSIR, Joypurhat following the standard procedures using Rigaku ZSX Primus equipped with an end window $4 \mathrm{KW}$ Rh-anode X-ray tube. The trace elements were determined by using crystal LiFi at a $40 \mathrm{kv}$ voltage with $60 \mathrm{~mA}$ current. Certified reference material SGR-1 was used in this work. Reference materials were firstly analyzed as unknown samples before analysis of selected sediments to ensure the standard deviation.

\subsection{Determination of Enrichment Factor of Soil Samples}

The extent of metal contamination compared to the background area was assessed using the enrichment factor, 


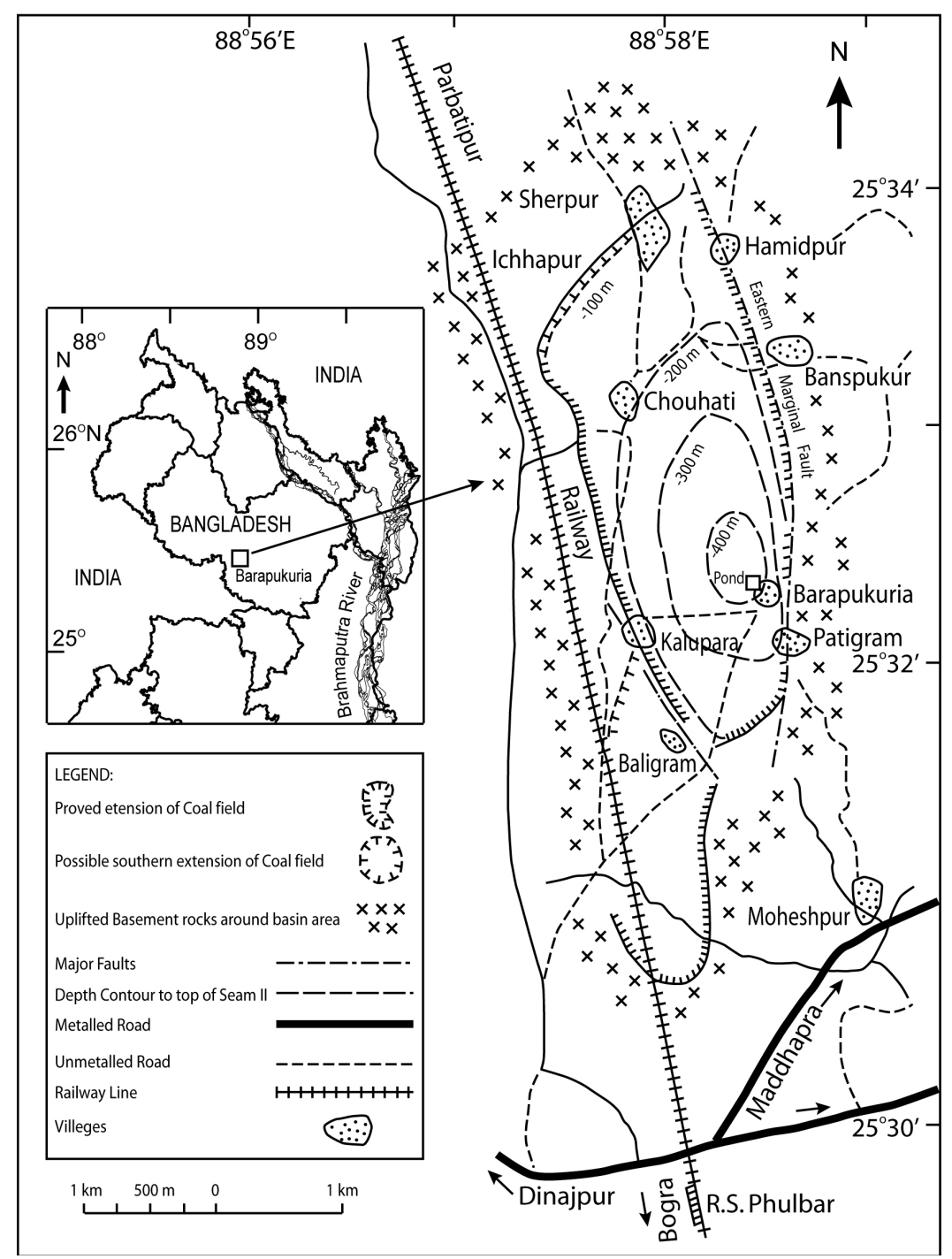

Figure 1. Location map of study area [4] (compiled from WA, 1991).

$E F$ [5] [6]. Metal concentrations were normalized to the textural characteristics of soils with respect to Fe [7]. According to Aprile and Bouvy (2008), the enrichment factor $(E F)$ for metal concentration in soils at all stations was calculated as Equation (1).

$$
E F=\frac{\mathrm{X} / \mathrm{Fe}(\text { sediment })}{\mathrm{X} / \mathrm{Fe}(\text { Earth's crust })}
$$

Iron was chosen as the element of normalization because of natural sources (98\%) vastly dominates its input [8]. The crustal abundance data of Krauskopf and Bird [9] were used for EF values.

\subsection{Determination of Geo-Accumulation Index ( $I_{g e o}$ ) of Soil Samples}

The geo-accumulation index for the metal concentrations in nine stations in BCMCL area was calculated using Muller's [10] expression and regional backgrounds available for this region (Muller's (1979) [11]-[14]). Abrahim and Paker (2008) [15] method was as Equation (2).

$$
I_{\text {geo }}=\log 2\left(\frac{[\text { sediment }]}{1.5 * \text { reference sample }}\right)
$$


The sediment pollution was investigated by following the concentration of nine studied trace metals such as Fe, Mn, Zn, Ni, Pb, Cu, Cd, Co and As. The factor 1.5 was introduced to minimize the effect of possible variations in sediments [16]. According to crustal abundance data of Krauskoph and Bird (1995) [9], the reference samples were Fe: 50,000, Mn: 950, Zn: 70, Ni: 75, Cr: 100, Pb: 13, Cu: 55, Cd: 0.2, Co: 25 and As: 1.8 mg/kg.

\subsection{Determination of Hakanson Potential Ecological Risk Index}

The potential ecological risk index method was proposed by Hakanson from a sedimentary perspective to assess the characteristics and environmental behavior of heavy metal contaminants in soil sediments. In addition to considering the heavy metals in soil, the Hakanson method assesses their potential ecological and environmental effects with toxicology. The assessment, which is conducted using parallel and equivalent index classification, provides a quantitative method of directly isolating the extent of potential hazards. This method is able to reflect the effects of various contaminants and reveal the comprehensive influence of multiple contaminants in a particular environment. The method comprises a single contamination coefficient, a comprehensive contamination measure, the toxic response factor for heavy metals, and a potential ecological risk index. The specific calculating formulas are as follows:

Equation (3) is the single contamination coefficient

$$
C_{f}^{i}=C_{s l}^{i} / C_{n}^{i}
$$

where $C_{f}^{i}$ is contamination coefficient of a particular heavy metal, $C_{s l}^{i}$ is the measured data of soil heavy metals, and $C_{n}^{i}$ is the reference value.

The comprehensive contamination was measured by using Equation (4)

$$
C_{d}=\sum C_{f}^{i}
$$

Equation (5) is the potential ecological risk index of a particular heavy metal

$$
E_{r}^{i}=T_{r}^{i} \cdot C_{f}^{i}
$$

where $T_{r}^{i}$ is the toxic response factor.

The potential ecological risk index was calculated by using Equation (6).

$$
R I=\sum E_{r}^{i}
$$

The corresponding degrees of contamination and the grading standards for the levels of potential ecological risk in $C_{f}^{i}, C_{d}, E_{r}^{i}$, and $R I$ based on relevant studies [17]-[19] are shown in Table 1.

Hakanson proposed the highest values of the heavy metals in sediments before the modern industrial era as reference values [20]. In this study background values were used as reference values to accurately reflect the pollution levels at BCMCL area. According to standardized toxic response factor proposed by Hakanson [21] $\mathrm{Cd}, \mathrm{Hg}$, As, Pb, Cr, Cu, Zn, and Ni have toxic response factors of 30, 40, 10, 5, 2, 22, 1, and 5, respectively.

\section{Results and Discussion}

The concentration of Fe was between 16,108 to 38,734 ppm, with an average value of 22,828.6 ppm. Fe concentration was found 38,734 ppm at St-6 and minimum was 16,108 ppm at St-2. The concentration of As was between 34.49 to 39.72, with an average value of 36.2, and the value of St-9 sample was above that of the back-

\begin{tabular}{|c|c|c|c|c|}
\hline & Class & Class & Class & Class \\
\hline$C_{f}^{i}$ & $<1$, non-contamination & $>-1,<2$, light & $>-2,<3$, moderate & $>-3$, heavy \\
\hline$C_{d}$ & $>8$, low & $>-8,<16$, moderate & $>16,<32$, relatively high & $>-32$, very high \\
\hline$E_{r}^{i}$ & $<40$, low & $>-40,<100$, strong & $>-100,<320$, very strong & $>-320$, extremely strong \\
\hline$R I$ & $<150$, low & $>150,<300$, moderate & $>-300,<600$, strong & $>-600$, very strong \\
\hline
\end{tabular}
ground soil. The concentration of Cr was between 33.62 and 90.7, with an average value of 47.39 and value of

Table 1. Degree of contamination for particular heavy metals and the corresponding grading standards for potential ecological risk. 
St-8 was below that of background soil but only St-1 had higher value (90.7) than that of its background. The Cu ranges from 40.1 to 51.49, with an average value of 43.75 and value of St-9 was above that of soil background. The concentration of Mn was between 117.15 and 900.52 with an average 261.79 and value of St- 8 was below that of its background soil but St-7(900.52) was exception. The concentration of $\mathrm{Zn}$ was between 44.43 and 110.56 with an average value of 57.63 and the value of St-5 was above that of background soil. The concentration of $\mathrm{Ni}$ was between 8.51 and 44.58 with an average value of 22.34 and the value of St- 4 was above that of background soil. The concentration of $\mathrm{Pb}$ was between 22.12 and 24.81 with an average value of 22.55 and values of all stations were little higher than that of its background soil. The Cd concentration in the studied samples were in lower concentration at all stations (0.76 - 0.89). The soil distribution characteristics of heavy metals in the study area are shown in Table 2.

Table 2. Metal concentrations in sediments collected from the surrounding area of BCMCL, Dinajpur.

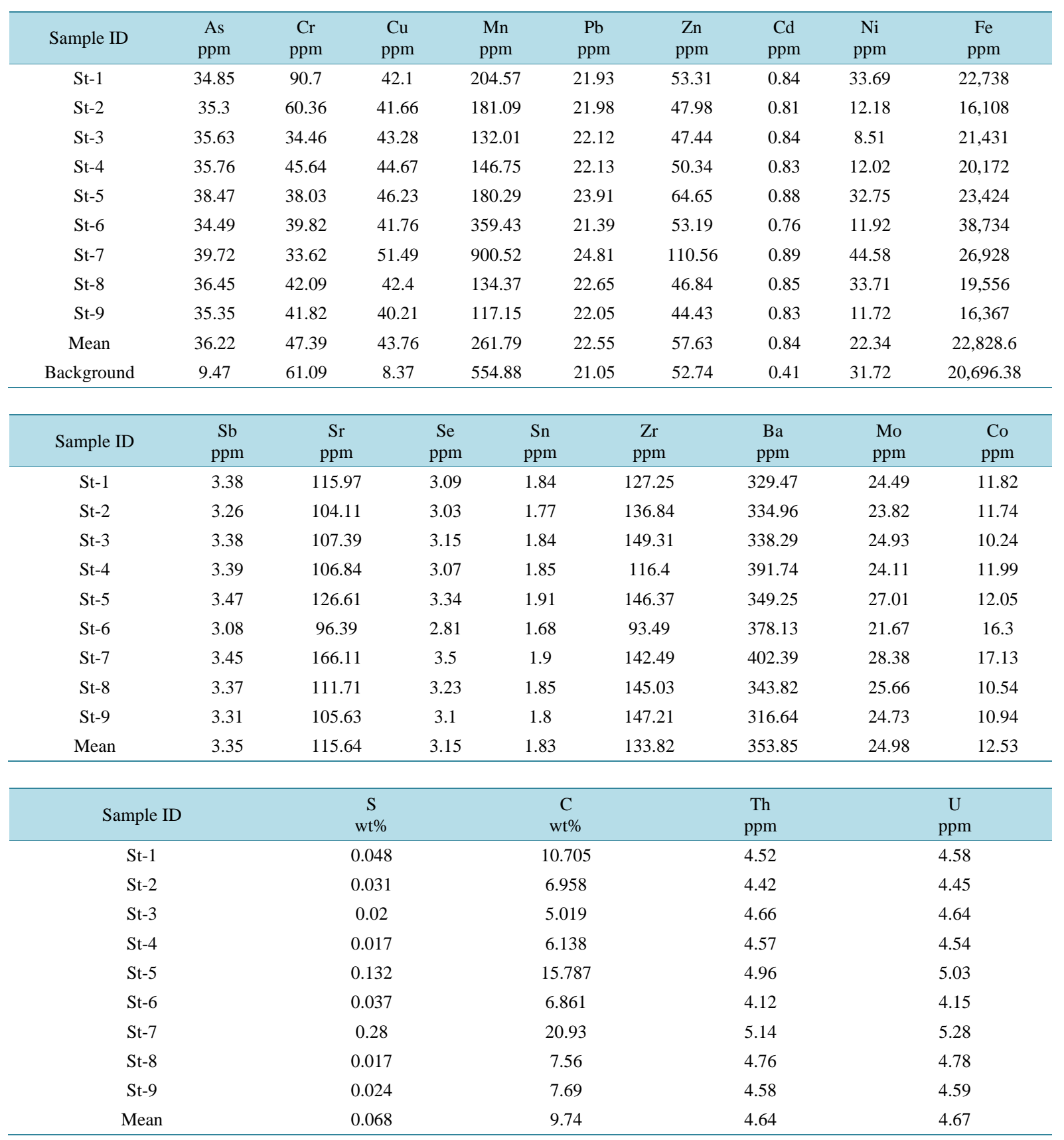


The heavy metal concentration in BCMCL area were in this order $\mathrm{Fe}>\mathrm{Ba}>\mathrm{Mn}>\mathrm{Zr}>\mathrm{Sr}>\mathrm{Cr}>\mathrm{Cu}>\mathrm{Zn}>$ As $>\mathrm{Ni}>\mathrm{Mo}>\mathrm{Pb}>\mathrm{Co}>\mathrm{Sb}>\mathrm{Se}>\mathrm{Sn}>\mathrm{Cd}$. Radioactive elements such as Thorium \& Urenium in this samples ranges from 4.12 to $5.14 \& 4.15$ to 5.28 respectively. Sulphur content of this studied area were very low (0.017 - 0.28) and Carbon content little high (6.13 - 20.93). The results were validated using two Certified Reference Materials (Soil-7 and SGR-1) as shown in Table 3. The experimental data was compared with certified data. Higher concentration of $\mathrm{Ba}$ (353.8) \& $\mathrm{Zr}$ (133.8) was found in the analyzed soil as compare to SGR-1 values. In study area the concentration of $\mathrm{Cu}, \mathrm{Ba}, \mathrm{Sb}$ and Se were higher as compared to Soil-7, Certified Reference Materials UGCS/SGR-1 and IAEA/Soil-7 [22].

The geoaccumulation Index of some heavy metals of soil samples in the BCMCL area were shown in Table 4. $I_{\text {geo }}$ values were interpreted with support of classification Table 5 of Abrahim and Paker [23]. Generally the $I_{\text {geo }}$ consists of 7 grades or classes.

The $I_{\text {geo }}$ classes for 10 studied heavy metals for each stations are listed in Table 6. The $I_{g e o}$ values revealed that the value of $\mathrm{Ni}, \mathrm{Fe}, \mathrm{Mn}, \mathrm{Cr}, \mathrm{Co}, \mathrm{Zn}$ and $\mathrm{Cu}$ in all stations fell into class 0 .This indicated that the sediments in these stations were uncontaminated by these metals. The $I_{\text {geo }}$ values for $\mathrm{Pb} \& \mathrm{Cd}$ in all stations were fell in class 1 . This indicated that sediments in these stations were uncontaminated to moderately contaminated by $\mathrm{Pb}$ and $\mathrm{Cd}$. The $I_{\text {geo }}$ values for As at all the stations fell in class 2 and this indicated that sediments in these stations were moderately contaminated by As. Some studied heavy metals (Ni, Mn, Cr, Co, Zn \& Cu) occured no contamination in that area. But the studied area at all stations were suffering from moderately contamination with As. That means As-toxicity was in moderate condition in BCMCL area.

The results of enrichment factor for nine studied heavy metals for each station were listed in Table 7. There is

Table 3. Comparison of detected values of heavy metals with two certified reference materials.

\begin{tabular}{ccccccccccccc}
\hline & $\mathrm{As}$ & $\mathrm{Cr}$ & $\mathrm{Cu}$ & $\mathrm{Mn}$ & $\mathrm{Ni}$ & $\mathrm{Pb}$ & $\mathrm{Zn}$ & $\mathrm{Cd}$ & $\mathrm{Ba}$ & $\mathrm{Zr}$ & $\begin{array}{c}\mathrm{Sb} \\
\mathrm{pb}\end{array}$ & $\begin{array}{c}\mathrm{Se} \\
\mathrm{ppm}\end{array}$ \\
\hline Analyzed soil & 36.2 & 47.39 & 43.7 & 261.79 & 22.34 & 22.55 & 57.63 & 0.84 & 353.8 & 133.8 & 3.3 & 3.1 \\
SGR-1 & 67 & 30 & 66 & 267 & 29 & 38 & 74 & 0.9 & 290 & 53 & 3.4 & 3.5 \\
Soil-7 & 13.4 & 60 & 11 & 631 & 26 & 60 & 104 & 1.3 & 159 & 185 & 1.7 & 0.4 \\
\hline
\end{tabular}

Table 4. The geoaccumulation Index of some heavy metals of soil samples in the BCMCL area, Dinajpur.

\begin{tabular}{cccccccccccc}
\hline Sample & $\mathrm{Pb}$ & $\mathrm{Cu}$ & $\mathrm{Cd}$ & $\mathrm{Zn}$ & $\mathrm{Co}$ & $\mathrm{Cr}$ & $\mathrm{As}$ & $\mathrm{Mn}$ & $\mathrm{Ni}$ & $\mathrm{FE}$ \\
\hline St-1 & 0.0510 & -0.2921 & 0.4471 & -0.2943 & -0.5014 & -0.2184 & 1.1108 & -0.8429 & -0.5236 & -0.5183 \\
$\mathrm{St}-2$ & 0.0519 & -0.2967 & 0.4313 & -0.3401 & -0.5043 & -0.3953 & 1.1164 & -0.8959 & -0.9655 & -0.6680 \\
St-3 & 0.0547 & -0.2801 & 0.4472 & -0.3450 & -0.5637 & -0.6387 & 1.1204 & -1.0332 & -1.1212 & -0.5440 \\
St-4 & 0.0549 & -0.2664 & 0.4419 & -0.3192 & -0.4952 & -0.5167 & 1.1220 & -0.9872 & -0.9712 & -0.5703 \\
St-5 & 0.0885 & -0.2515 & 0.4673 & -0.2106 & -0.4930 & -0.5959 & 1.1537 & -0.8978 & -0.5359 & -0.5054 \\
St-6 & 0.0401 & -0.2956 & 0.4036 & -0.2953 & -0.3618 & -0.5759 & 1.1063 & -0.5982 & -0.9748 & -0.2869 \\
St-7 & 0.1045 & -0.2047 & 0.4722 & 0.0224 & -0.3402 & -0.6494 & 1.1676 & -0.1993 & -0.4020 & -0.4448 \\
St-8 & 0.0650 & -0.2890 & 0.4523 & -0.3505 & -0.5511 & -0.5519 & 1.1303 & -1.0255 & -0.5233 & -0.5837 \\
St-9 & 0.0533 & -0.3121 & 0.4419 & -0.3735 & -0.5350 & -0.5547 & 1.1170 & -1.0850 & -0.9822 & -0.6610 \\
\hline
\end{tabular}

Table 5. The degree of metal pollution of seven enrichment classes (Abrahim \& Paker, 2008).

\begin{tabular}{ccc}
\hline$I_{g e o}$ value & $I_{g e o}$ class & Class designation of sediment quality \\
$>5$ & 6 & Extremely contaminated \\
$4-5$ & 5 & Strongly to extremely contaminated \\
$3-4$ & 4 & Strongly to Contaminated \\
$2-3$ & 3 & Moderately to strongly contaminated \\
$1-2$ & 2 & Moderately contaminated \\
$0-1$ & 1 & Uncontaminated to moderately contaminated \\
$<0$ & 0 & Uncontaminated
\end{tabular}


Table 6. The results of geoaccumulation index classes of heavy metals of BCMCL area, Dinajpur.

\begin{tabular}{cccccccccccc}
\hline Sample & $\mathrm{Pb}$ & $\mathrm{Cu}$ & $\mathrm{Cd}$ & $\mathrm{Zn}$ & $\mathrm{Co}$ & $\mathrm{Cr}$ & $\mathrm{As}$ & $\mathrm{Mn}$ & $\mathrm{Ni}$ & $\mathrm{Fe}$ \\
\hline St-1 & 1 & 0 & 1 & 0 & 0 & 0 & 2 & 0 & 0 & 0 \\
St-2 & 1 & 0 & 1 & 0 & 0 & 0 & 2 & 0 & 0 & 0 \\
St-3 & 1 & 0 & 1 & 0 & 0 & 0 & 2 & 0 & 0 & 0 \\
St-4 & 1 & 0 & 1 & 0 & 0 & 0 & 2 & 0 & 0 & 0 \\
St-5 & 1 & 0 & 1 & 0 & 0 & 0 & 2 & 0 & 0 & 0 \\
St-6 & 1 & 0 & 1 & 0 & 0 & 0 & 2 & 0 & 0 & 0 \\
St-7 & 1 & 0 & 1 & 0 & 0 & 0 & 2 & 0 & 0 & 0 \\
St-8 & 1 & 0 & 1 & 0 & 0 & 0 & 2 & 0 & 0 & 0 \\
St-9 & 1 & 0 & 1 & 0 & 0 & 0 & 2 & 0 & 0 & 0 \\
Mean & 1 & 0 & 1 & 0 & 0 & 0 & 2 & 0 & 0 & 0 \\
\hline
\end{tabular}

Table 7. The results of enrichment factor of heavy metals of sediment samples of BCMCL area.

\begin{tabular}{cccccccccccc}
\hline Sample & As & Co & $\mathrm{Cr}$ & $\mathrm{Cu}$ & $\mathrm{Mn}$ & $\mathrm{Pb}$ & $\mathrm{Zn}$ & $\mathrm{Nd}$ & \\
St-1 & 42.5743 & 1.0396 & 1.9944 & 1.6832 & 0.4735 & 3.7094 & 1.6746 & 0.9877 & 9.2356 \\
St-2 & 60.8738 & 1.4576 & 1.8736 & 2.3511 & 0.5917 & 5.2482 & 2.1276 & 0.5041 & 12.571 \\
St-3 & 46.1818 & 0.9556 & 0.8039 & 1.8359 & 0.3242 & 3.9698 & 1.5812 & 0.2647 & 9.7988 \\
St-4 & 49.2432 & 1.1887 & 1.1312 & 2.0131 & 0.3829 & 4.2194 & 1.7825 & 0.3972 \\
St-5 & 45.6204 & 1.0288 & 0.8117 & 1.7942 & 0.4051 & 3.9259 & 1.9714 & 0.9320 \\
St-6 & 24.7342 & 0.8416 & 0.5140 & 0.9801 & 0.4884 & 2.1239 & 0.9808 & 0.2051 \\
St-7 & 40.9735 & 1.2722 & 0.6242 & 1.7383 & 1.7601 & 3.5436 & 2.9327 & 1.1036 \\
St-8 & 51.7744 & 1.0779 & 1.0761 & 1.9710 & 0.3616 & 4.4546 & 1.7108 \\
St-9 & 59.9954 & 1.3368 & 1.2775 & 2.2334 & 0.3767 & 5.1816 & 1.9390 & 1.1492 \\
\hline
\end{tabular}

no accepted pollution ranking system or categorization of degree of pollution on the enrichment ratio and/or factor methodology. Five contamination categories are recognized on the basis of enrichment factor: $E F<2$ states deficiency to minimal enrichment, $E F=2-5$ moderate enrichment, $E F=5-20$ significant enrichment, $E F=20-40$ very high enrichment and $E F>40$ extremely high enrichment [24] [25]. Enrichment factors of heavy metals were calculated for each soil sample relative to the background values of abundance of chemical elements in the continental earth crust, choosing Fe as the reference element.

According to the classification (Sezgin et al., 2003 [25]), Cd results (12.67 - 4.90) showed that eight stations have significant enrichment and St-6 have moderate enrichment. The heavy metals $\mathrm{Zn}, \mathrm{Cu}, \mathrm{Mn}$ and Ni showed deficiency to minimal enrichment. Mn (1.76 - 0.32) showed deficiency to minimal enrichment at every station. As ranges from 24.73 - 60.87 which have extremely high enrichment at eight stations and only St-6 (24.73) have very high enrichment. These results revealed that the soils in these stations were in extremely high enrichment condition by As metal. Co ranges from 1.45 - 0.84 which has deficiency to minimal enrichment. We saw Cr (1.99 - 0.51) have deficiency to minimal enrichment at all stations. Cu ranges from 2.35 - 0.98 that means six stations have (<2 values) deficiency to minimal enrichment and at stations 2, 4 \& 9 (2.35, 2.01 \& 2.23) have moderate enrichment. In case of $\mathrm{Pb}$ (5.24 - 2.12) seven stations have moderate enrichment and St-2 \& 9 (5.24 \& 5.18) have significant enrichment. Zn ranges from $2.93-0.98$ that means seven stations have deficiency to minimal enrichment but station 2 and 7 showed exception (2.12 \& 2.93) moderate enrichment. For Ni (range 1.14 0.20 ), every station have deficiency to minimal enrichment.

Hakanson potential ecological risk method: The single contamination indices $\left(C_{f}^{i}\right)$ and the overall contamination $\left(C_{d}\right)$ of heavy metals in BCMCL soils were shown in Table 8 . The degree of soil contamination at the Barapukuria coal mine area ranged from 12.48 to 18.20 , with an average value of 14.27, reflecting moderate contamination. The order of contamination of the eight heavy metals is $\mathrm{Cu}>\mathrm{As}>\mathrm{Cd}>\mathrm{Zn}>\mathrm{Pb}>\mathrm{Cr}>\mathrm{Ni}>\mathrm{Mn}$ and the order of contamination at the sites is St-7 $>$ St- $->$ St $-1>$ St $-6>$ St $-8>$ St $-4>$ St $-2>$ St $-3>$ St-9. The 
average value of contamination coefficients was between 0.47 and 5.22, indicating a light level (followed by Table 1) of contamination. Cu had the largest contamination coefficient, especially in the St-7 (6.15), indicating heavy contamination. The contamination coefficient of As ranges from 3.64 to 4.19, that indicates heavy contamination at every stations. In case of $\mathrm{Pb}$, the contamination coefficient at all stations was $>1$ that indicates light contamination. Comprehensive contamination $\left(C_{d}\right)$ ranges 12.48 to 18.50 , average value is 14.27 which represents moderate level of contamination and only St-7 has relatively high class of $C_{d}$.

The potential ecological risk index of a particular heavy metal $\left(E_{r}^{i}\right)$ in the soil of BCMCL area was calculated according to Hakanson index method and its division standard and the results are shown in Table 9. The risk coefficients of As in most of soil samples were low. Among seven heavy metals, the level of contamination posed low potential (followed by Table 1) ecological risk, with an index of between 1.09 to 38.25 and only Cd has 61.21. The risk coefficients of $\mathrm{As}, \mathrm{Pb}, \mathrm{Cr}, \mathrm{Ni}, \mathrm{Zn}, \mathrm{Cd}$ and $\mathrm{Cu}$ at every station was low, indicating that these seven heavy metals had a limited environmental impact on BCMCL area. The order of ecological risk associated with seven heavy metals is $\mathrm{Cd}>\mathrm{As}>\mathrm{Cu}>\mathrm{Pb}>\mathrm{Ni}>\mathrm{Cr}>\mathrm{Zn}$. Cd has the highest potential ecological risk index and poses greatest damage to the BCMCL area's soil. Zn plays an important role in plant nutrition \& has a relatively lower toxicity response factor. Here $\mathrm{Zn}$ represents least ecological hazard.

The potential ecological risk index $(R I)$ is a comprehensive measure of the degree of contamination and potential ecological hazard of total heavy metals. Here seven heavy metals were calculated because standard toxic

Table 8. Contamination indices $\left(C_{f}^{i}\right)$ and the overall contamination of heavy metals in BCMCL soils.

\begin{tabular}{|c|c|c|c|c|c|c|c|c|c|c|}
\hline \multirow{2}{*}{ Sample } & \multicolumn{8}{|c|}{$C_{f}^{i}$} & \multirow{2}{*}{$C_{d}$} & \multirow{2}{*}{$C_{d}$ level } \\
\hline & As & $\mathrm{Cr}$ & $\mathrm{Cu}$ & $\mathrm{Mn}$ & $\mathrm{Ni}$ & $\mathrm{Cd}$ & $\mathrm{Pb}$ & $\mathrm{Zn}$ & & \\
\hline St-1 & 3.68 & 1.48 & 5.02 & 0.37 & 1.06 & 2.04 & 1.04 & 1.01 & 14.77 & Moderate \\
\hline St-2 & 3.72 & 0.98 & 4.97 & 0.32 & 0.38 & 1.975 & 1.04 & 0.90 & 13.13 & Moderate \\
\hline St-3 & 3.76 & 0.56 & 5.17 & 0.23 & 0.26 & 2.04 & 1.05 & 0.89 & 12.98 & Moderate \\
\hline St-4 & 3.77 & 0.74 & 5.33 & 0.26 & 0.37 & 2.02 & 1.05 & 0.95 & 13.48 & Moderate \\
\hline St-5 & 4.06 & 0.62 & 5.52 & 0.32 & 1.03 & 2.14 & 1.13 & 1.23 & 15.05 & Moderate \\
\hline St-6 & 3.64 & 0.65 & 4.98 & 0.64 & 0.37 & 1.85 & 1.01 & 1.008 & 14.20 & Moderate \\
\hline St-7 & 4.19 & 0.55 & 6.15 & 1.62 & 1.40 & 2.17 & 1.17 & 2.09 & 18.50 & Relatively high \\
\hline St-8 & 3.84 & 0.68 & 5.06 & 0.24 & 1.06 & 2.07 & 1.07 & 0.88 & 13.81 & Moderate \\
\hline St-9 & 3.73 & 0.68 & 4.80 & 0.21 & 0.37 & 2.02 & 1.04 & 0.84 & 12.48 & Moderate \\
\hline Average & 3.82 & 0.77 & 5.22 & 0.47 & 0.70 & 2.04 & 1.07 & 1.09 & 14.27 & Moderate \\
\hline $\begin{array}{c}\text { Contamination } \\
\text { degree }\end{array}$ & Heavy & Non-conta & Heavy & Non-conta & Non-conta & Moderate & Light & Light & & Moderate \\
\hline
\end{tabular}

Table 9. Ecological risk factor and potential ecological risk index (RI) of heavy metals in BCMCL area.

\begin{tabular}{|c|c|c|c|c|c|c|c|c|c|}
\hline \multirow{2}{*}{ Sample } & \multicolumn{7}{|c|}{$E_{r}^{i}$} & \multirow{2}{*}{$R I$} & \multirow{2}{*}{$\begin{array}{l}\text { Risk } \\
\text { grade }\end{array}$} \\
\hline & As & $\mathrm{Cr}$ & $\mathrm{Cu}$ & $\mathrm{Ni}$ & $\mathrm{Pb}$ & $\mathrm{Zn}$ & $\mathrm{Cd}$ & & \\
\hline St-1 & 36.80 & 2.96 & 25.14 & 5.31 & 5.20 & 1.01 & 61.46 & 137.91 & Low \\
\hline St-2 & 37.27 & 1.97 & 24.88 & 1.91 & 5.22 & 0.90 & 59.27 & 131.45 & Low \\
\hline St-3 & 37.62 & 1.12 & 25.85 & 1.34 & 5.25 & 0.89 & 61.46 & 133.56 & Low \\
\hline St-4 & 37.76 & 1.49 & 26.68 & 1.89 & 5.26 & 0.95 & 60.73 & 134.77 & Low \\
\hline St-5 & 40.62 & 1.24 & 27.61 & 5.16 & 5.67 & 1.22 & 64.39 & 145.94 & Low \\
\hline St-6 & 36.42 & 1.30 & 24.94 & 1.87 & 5.08 & 1.008 & 55.61 & 126.24 & Low \\
\hline St-7 & 41.94 & 1.10 & 30.75 & 7.02 & 5.89 & 2.096 & 65.12 & 153.94 & Moderate \\
\hline St-8 & 38.48 & 1.37 & 25.32 & 5.31 & 5.38 & 0.89 & 62.19 & 138.97 & Low \\
\hline St-9 & 37.32 & 1.36 & 24.02 & 1.85 & 5.24 & 0.84 & 60.73 & 131.37 & Low \\
\hline Average & 38.25 & 1.55 & 26.14 & 3.52 & 5.32 & 1.09 & 61.21 & 137.13 & Low \\
\hline$E_{r}^{i}$ grade & Low & Low & Low & Low & Low & Low & Moderate & & \\
\hline
\end{tabular}



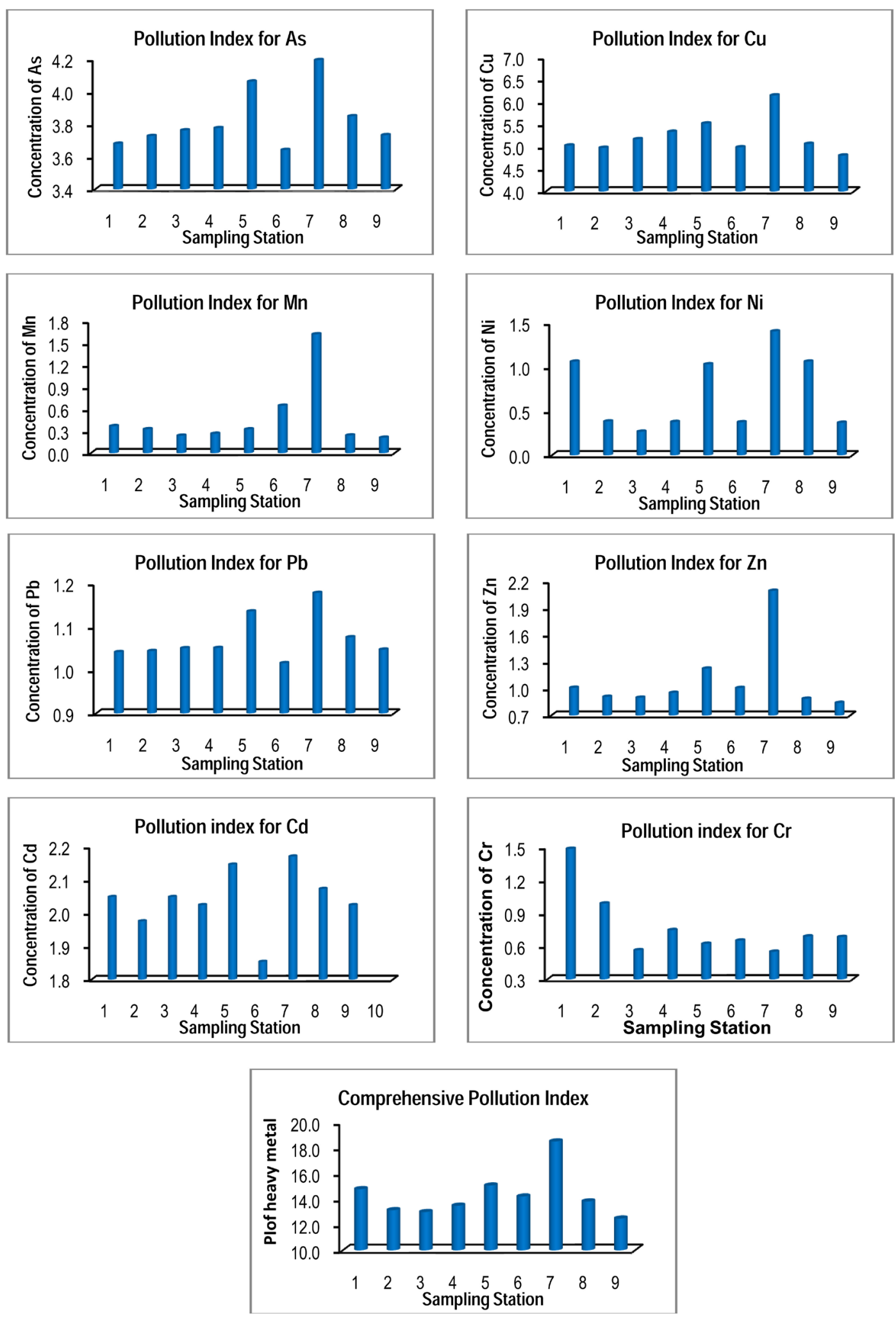

Figure 2. Soil contamination indices of heavy metals in the study area.

response factor proposed by Hakanson has no value for Mn. So, Manganese is not shown in Table 9. The potential ecological risk index of heavy metals found at BCMCL area ranged from 126.24 to 153.94, with an average 
value of 137.13, representing a low ecological risk (followed by Table 1) and only st-7 fell under moderate class of RI. Thus comprehensive treatment of heavy metals especially for Cd should be started to improve environmental protection at that site. The soil contamination indices or pollution index (PI) of heavy metals in study area are shown graphically in Figure 2.

\section{Conclusions}

The soil samples collected from surrounding area of Barapukuria Coal Mine Company Limited have been studied in this study. The concentration of heavy metal (Cd, As, Pb, Cr, Cu, Zn, Ni and Mn) and their contamination levels of that area were determined. The enrichment factor, geoaccumulation index and Hakanson potential ecological risk index were used to analyze the level of contamination and potential ecological toxicity of heavy metals in that area.

1) The enrichment factor $(E F)$ results indicated that the soil of BCMCL area was in extremely high enrichment condition by As metal. Co has deficiency to minimal enrichment at that site. Pb has moderate enrichment in seven stations and significant enrichment in two stations.

2) According to geoaccumulation index ( $I_{\text {geo }}$ ) values, the sediment of BCMCL area was suffering from uncontaminated to moderate contamination with $\mathrm{Pb}$ and $\mathrm{Cd}$. The studied areas at all stations were suffering from moderate contamination with As. That means As-toxicity was in moderate condition in BCMCL area.

3) According to Hakanson potential ecological risk index, the level of soil contamination ( $C_{d}$ level) at BCMCL area reflects moderate contamination. The order of contamination coefficients $\left(C_{f}^{i}\right)$ of eight heavy metals is as follows: $\mathrm{Cu}>\mathrm{As}>\mathrm{Cd}>\mathrm{Zn}>\mathrm{Pb}>\mathrm{Cr}>\mathrm{Ni}>\mathrm{Mn}$. The average value of contamination coefficients indicates a light level of contamination. The contamination coefficient of As and $\mathrm{Cu}$ indicates heavy contamination at that area. So, targeted pollution control and management measures are urgently required to prevent the increase of As \& Cu contamination and to limit potential harm.

4) By considering potential ecological risk index of a particular heavy metal $\left(E_{r}^{i}\right)$ the order is as follows: $\mathrm{Cd}>\mathrm{As}>\mathrm{Cu}>\mathrm{Pb}>\mathrm{Ni}>\mathrm{Cr}>\mathrm{Zn}$. Cd has the highest potential ecological risk index and poses greatest damage to this area. The potential ecological risk index $(R I)$ and $R I$ grade showed low ecological risk in this area.

5) The overall results showed that there is a moderate contamination at BCMCL area. Therefore the contamination control and comprehensive treatment of heavy metals should be strengthened, specifically for $\mathrm{As}, \mathrm{Cu}$ and Cd to improve the ecological restoration and environmental protection at that site.

\section{Acknowledgements}

The Research and Development (R\&D) project has been submitted to the BCSIR through Director, IMMM for financial year 2010-2011. The project was approved at 25th May, 2011. We would like to thank Chairman, BCSIR for approval of this R\&D project and guideline to complete the project. We also thank to Director, IMMM, BCSIR, Joypurhat for his cooperation and inspiration. We are also grateful to the scientists, technicians and lab attendants for their support to complete the project.

\section{References}

[1] Akcil, A. and Koldas, S. (2006) Acid Mine Drainage (AMD) Causes, Treatment and Case Studies. Journal of Cleaner Production, 14, 1139-1145. http://dx.doi.org/10.1016/j.jclepro.2004.09.006

[2] Cherry, D.S., Currie, R.J., Souek, D.J., Latimer, H.A. and Trent, G.C. (2001) An Integrative Assessment of a Watershed Impacted by Abandoned Mined Land Discharges. Environmental Pollution, 111, 377-388. http://dx.doi.org/10.1016/S0269-7491(00)00093-2

[3] Gergen, I. and Harmanescu, M. (2012) Application of Principal Component Analysis in the Pollution Assessment with Heavy Metals of Vegetable Food Chain in the Old Mining Areas. Chemistry Central Journal, 6, 156. http://dx.doi.org/10.1186/1752-153X-6-156

[4] Armstrong, W. (1991) Techno-Feasibility Study of the Barapukuria Coal Project. Dinajpur, Bangladesh, Vol. 1.

[5] Selvaraj, K., Ram Mohan, V. and Szefer, P. (2004) Evaluation of Metal Contamination in Coastal Sediments of the Bay of Bengal, India: Geochemical and Statistical Approaches. Marine Pollution Bulletin, 49, 174-185. http://dx.doi.org/10.1016/j.marpolbul.2004.02.006

[6] Woitke, P., Wellmitz, J., Helm, D., Kube, P., Lepom, P. and Litheraty, P. (2003) Analysis and Assessment of Heavy Metal Pollution in Suspended Solids and Sediments of the River Danube. Chemosphere, 51, 633-642. 
http://dx.doi.org/10.1016/S0045-6535(03)00217-0

[7] Aprile, F.M. and Bouvy, M. (2008) Distribution and Enrichment of Heavy Metals in Sediments at the Tapacura River Basin, Northeastern Brazil. Brazilian Journal of Aquatic Sciences and Technology, 12, 1-8. http://dx.doi.org/10.14210/bjast.v12n1.p1-8

[8] Kamau, J.N. (2002) Heavy Metal Distribution and Enrichment at Port-Reitz Creek, Mombasa. Western Indian Ocean Journal of Marine Science, 1, 65-70.

[9] Krauskoph, K.B. and Bird, D.K. (1995) Introduction to Geo-Chemistry. 3rd Edition, McGraw-Hill, Inc., New York, $647 \mathrm{p}$.

[10] Angelidis, M.O. and Aloupi, M. (1995) Metals in Sediments of Rhoders Harbour, Greece. Marine Pollution Bulletin, 31, 273-276. http://dx.doi.org/10.1016/0025-326X(95)00148-G

[11] Rubio, B., Nombela, M.A. and Vilas, F. (2000) Geochemistry of Major and Trace Elements in Sediments of the Ria de Vigo (NW Spain): An Assessment of Metal Pollution. Marine Pollution Bulletin, 40, 968-980. http://dx.doi.org/10.1016/S0025-326X(00)00039-4

[12] Sahu, K.C. and Bhosle, U. (1991) Heavy Metal Pollution around the Island City of Bmbay, India. Part 1: Quantification of Heavy Metal Pollution of Aquatic Sediments and Recognition of Environmental Discriminants. Chemical Geology, 91, 263-283. http://dx.doi.org/10.1016/0009-2541(91)90104-Y

[13] Subramanian, V. and Mohanachandran, G. (1990) Heavy Metals Distribution and Enrichment in Sediments of Southern East Coast of India. Marine Pollution Bulletin, 21, 324-330. http://dx.doi.org/10.1016/0025-326X(90)90792-7

[14] Muller, G. (1979) Schwermetalle in den sediments des Rheins-Veranderugen seitt 1971. Umschan, 79, 778-783.

[15] Abrahim, G.M.S. and Paker, R.J. (2008) Assessment of Heavy Metal Enrichment Factors and the Degree of Contamination in Marine Sediments from Tamaki Estuary, Auckland, New Zealand. Environmental Monitoring and Assessment, 136, 227-238. http://dx.doi.org/10.1007/s10661-007-9678-2

[16] Al-Haidarey, M.J.S., Hasan, F.M., Al-Kubaisey, A.R.A. and Douabul, A.A.Z. (2010) The Geoaccumulation Index of Some Heavy Metals in Al-Hawizeh Marsh, Iraq. E-Journal of Chemistry, 7, S157-S162.

http://dx.doi.org/10.1155/2010/839178

[17] Dong, J., Bian, Z. and Wang, H. (2007) Comparison of Heavy Metal Contents between Different Reclaimed Soils and the Control Soil. Journal of China University of Mining and Technology, 3, 531-536.

[18] Lee, S., Lee, B., Kim, J., Kim, K. and Lee, J. (2006) Human Risk Assessment for Heavy Metals and as Contamination in the Abandoned Metal Mine Areas, Korea. Environmental Monitoring and Assessment, 119, 233-244. http://dx.doi.org/10.1007/s10661-005-9024-5

[19] Jiao, B., Xu, G., Li, D., Luo, J. and Yang, K. (2002) Hazards of Heavy Metals in Coal. Disaster Advances, 5, 18121818.

[20] Wang, Y. and Dong, J. (2009) Potential Ecological Risk Assessment of Filling Reclaimed Soils Polluted by Heavy Metals in Mining Area. Journal of China Coal Society, 34, 650-655.

[21] Qu, C., Sun, K., Wang, S., Huang, L. and Bi, J. (2012) Monte Carlo Simulation-Based Health Risk Assessment of Heavy Metal Soil Pollution: A Case Study in the Qixia Mining Area, China. Human and Ecological Risk Assessment, 18, 733-750. http://dx.doi.org/10.1080/10807039.2012.688697

[22] IAEA/RL/112 (1984) Report on the Intercomparison Run IAEA-Soil-7. Trace Elements in Soil. IAEA, Vienna.

[23] SGR-1 (2014) United States Geological Survey Certificate of Analysis. Reference Material Project, CGGSC, SGR-1, Denver.

[24] Duzgoren-Aydin, N.S., Wong, C.S.C., Aydin, A., Song, Z., You, M. and Li, X.D. (2006) Heavy Metal Contamination and Distribution in the Urban Environment of Guangzhou, SE China. Environmental Geochemistry and Health, 28, 375-391. http://dx.doi.org/10.1007/s10653-005-9036-7

[25] Sezgin, N., Ozcan, H.K., Demir, G., Nemlioglu, S. and Bayat, C. (2003) Determination of Heavy Metal Concentrations in Street Dusts in Istanbul E-5 Highway. Environment International, 29, 979-985. http://dx.doi.org/10.1016/S0160-4120(03)00075-8 